ASIMETRIS: JURNAL PENDIDIKAN MATEMATIKA DAN SAINS

$$
\text { p-ISSN } 2721 \text { - 8724, e-ISSN } 2722 \text { - } 0214
$$

Website Jurnal: http://journal.umuslim.ac.id/index.php/asm/

\begin{aligned} & Info Artikel: Direvisi pada 17 Oktober 2021 \\ & Disubmit pada 10 Oktober 2021 Diterima pada 20 Oktober 2021 \\ & Direview pada 15 Oktober 2021 Tersedia secara daring pada 28 Oktober 2021 \\ & \hline\end{aligned}

\title{
MENINGKATKAN KEMAMPUAN BERPIKIR KREATIF MATEMATIS SISWA DENGAN PENDEKATAN PROBLEM POSING
}

\author{
Feri Irawan \\ SMK Negeri 1 Bireuen, Aceh, Indonesia \\ Alamat email: ferifodic78@gmail.com
}

\begin{abstract}
ABSTRAK. Ada beberapa tujuan dari penelitian ini yaitu untuk mengetahui perbedaan peningkatan kemampuan berpikir kreatif matematis siswa menggunakan model pembelajaran Problem Posing dengan pembelajaran secara konvensional, untuk mengetahui perbedaan peningkatan kemampuan berpikir kreatif matematis siswa berdasarkan pengetahuan awal matematika dengan model pembelajaran Problem Posing, dan intuk mengetahui interaksi antara pengetahuan awal matematika siswa dengan pembelajaran yang digunakan terhadap peningkatan kemampuan berpikir kreatif matematis siswa. Jenis penelitian yang digunakan menggunakan quasi eksperimen dengan desain penelitian non-equivalen control group design. Populasinya adalah semua siswa kelas XII SMKN 1 Bireuen, dan sampelnya adalah kelas XII TKJ 1 sebagai kelas eksperimen dan kelas XII TKJ 2 sebagai kelas kontrol. Pengambilan kelas eksperimen dan kelas kontrol dilakukan dengan teknik purposive sampling. Hasil penelitian menunjukkan bahwa siswa yang memperoleh pembelajaran Problem Posing lebih baik dari pembelajaran konvensional terhadap kemampuan berpikir kreatif matematis. Terjadi perbedaan nilai pengetahuan awal matematika terhadap peningkatan kemampuan berpikir kreatif matematis siswa, sedangkan berdasarkan jenis kelamin siswa tidak terjadi perbedaan. Terjadi interaksi antara pengetahuan awal matematika siswa dengan pembelajaran yang digunakan. terhadap peningkatan kemampuan berpikir kreatif matematis siswa.
\end{abstract}

Kata Kunci: Berpikir Kreatif Matematis, Problem Posing

ABSTRACT. There are several objectives of this study, namely to determine the differences in increasing students' mathematical creative thinking skills using the Problem Posing learning model with conventional learning, to determine the differences in students' mathematical creative thinking skills improvement based on prior knowledge of mathematics with the Problem Posing learning model, and to determine the interaction between students' initial knowledge of mathematics with learning used to increase students' mathematical creative thinking skills. This type of research used quasi-experimental research design with nonequivalent control group design. The population is all class XII students of SMKN 1 Bireuen, and the samples are class XII TKJ1 as the experimental class and class XII TKJ2 as the control class. The experimental class and control class were taken using purposive sampling technique. The results showed that students who received Problem Posing learning were better than conventional learning on the ability to think creatively mathematically. There was a difference in the value of the initial knowledge of mathematics in increasing students' mathematical creative thinking skills, while based on the gender of the students there was no difference. There was an interaction between students' prior knowledge of mathematics and the learning used. to increase students' mathematical creative thinking skills.

Keywords: Mathematical Creative Thinking, Problem Posing

\section{PENDAHULUAN}

Kemampuan matematika pada hakikatnya mengajarkan siswa agar mampu menghadapi masalah dalam proses pembelajaran matematika ataupun pada kehidupan nyata. Menurut Kurikulum 2013 dalam Permendikbud No. 22 Tahun 2016, menyatakan bahwa kemampuan berpikir kreatif merupakan salah satu kemampuan matematis yang harus dimiliki siswa. Maulana dalam (Nenden \& 
Isrok'atun, 2016) menyatakan seseorang yang memiliki kemampuan berpikir kreatif, maka ia dapat menyatakan dan menggungkapkan hubungan baru, melihat masalah dari sudut pandang yang baru, membentuk kombinasi baru dari beberapa konsep yang sudah dikuasai sebelumnya, bersifat praktis, dan memunculkan solusi tidak lazim.

Kemampuan berpikir kreatif matematis diartikan sebagai suatu kemampuan dengan menemukan dan penyelesaian masalah matematika seperti komponen-komponen: keaslian (orisinalitas), fleksibel, kelancaran, dan elaborasi. Menurut Hendriana dalam (Darwanto, 2019) kemampuan berpikir kreatif matematis merupakan salah satu hard skills matematika.

Namun berdasarkan data hasil penelitian tes kemampuan berpikir kreatif matematis terhadap 34 siswa kelas XII TKJ SMKN 1 Bireuen tanggal 5 Desember 2019, diperoleh bahwa kemampuan berpikir kreatif matematis siswa berada di kategori rendah sebesar 2 orang $(5,88 \%)$, kemampuan berpikir kreatif matematis siswa berada pada kategori sedang sebesar 32 orang $(94,12 \%)$, OLeh karena iru, tidak ada siswa yang memiliki kemampuan berpikir kreatif matematis siswa pada kategori tinggi. Kemampuan berpikir kreatif matematis siswa rata-rata sebesar 36,76 , dengan nilai minimum 15,63 dan nilai maksimum 75. Ini menunjukkan bahwa kemampuan berpikir kreatif matematis siswa kelas XII SMKN 1 Bireuen umumnya masih rendah.

Rendahnya kemampuan berpikir kreatif matematis siswa diduga karena 1) siswa cenderung tidak menjawab pertanyaan guru ketika diberikan pertanyaan, sehingga hal tersebut belum menunjukan kelancaran siswa dalam mengemukakan gagasan, 2) dalam menjawab pertanyaan siswa masih menggunakan cara sendiri, dan 3) siswa tidak pernah dilatih untuk mengerjakan soal-soal yang berkaitan dengan kemampuan berpikir kreatif. Hasil Wawancara Peneliti dengan 3 orang Guru matematika di SMKN 1 Bireuen tanggal 5 Desember 2019 menyatakan bahwa siswa tidak terlatih dalam hal menjawab soal dan mencari solusi tugas-tugas dengan kemampuan yang mereka miliki, sehingga membuat mereka tidak berani untuk mengunggkapkan ide baru yang mereka miliki.

Salah satu usaha yang dapat diterapkan adalah melakukan inovasi dalam pembelajaran. Ausubel Russefebdi dalam (Irawan, 2013) juga menyarankan dalam pembelajaran diterapkan pendekatan degan metode pemecahan masalah dan metode belajar yang dapat menumbuhkan berpikir kreatif.

Berdasarkan pernyataan-pernyataan diatas salah satunya dengan kegiatan pembangkit masalah (Riedesel dalam (Irawan, 2013). maka pendekatan yang tepat untuk diterapkan pada pembelajaran matematika dan dalam rangka merangsang munculnya kemampuan berpikir kreatif matematis siswa adalah pembelajaran dengan pendekatan problem posing. Sependapat dengan diatas, Russefendi (Irawan, 2013) mengatakan bahwa uhasa membantu siswa memahami soal dapat dilakukan dengan menulis kembali soal tersebut dengan kata-katanya sendiri, menulis soal dalam bentuk lain atau dalam bentuk operasional.

Penerapan model pembelajaran dengan problem posing, perlu diperhatikan beberapa hal yang dapat meningkatkan kemampuan berpikir kreatif matematis siswa. Diantaranya adalah pengetahuan awal matematika, dan perbedaan jenis kelamin siswa. Menurut Nur dalam (Subhan \& Pamungkas, 2017) yang menyatakan bahwa pengetahuan awal merupakan kumpulan pengetahuan seseorang yang diperolehnya selama pembelajaran dan akan dibawa kepada suatu pengalaman belajar baru. Siswa yang memiliki pengetahuan awal yang baik akan memperoleh pengetahuan baru yang baik pula, dan sebaliknya. Oleh karena itu, kemampuan berpikir kreatif dapat dioptimalkan, maka pengetahuan awal harus sudah ada terlebih dahulu oleh siswa. Faktor ini diprediksikan berpengaruh terhadap hasil penerapan pembelajaran dengan problem posing dalam upaya meningkatkan kemampuan berpikir kreatif matematis siswa. 
Berdasarkan paparan di atas, penulis menduga bahwa pendekatan problem posing dapat mempengaruhi kemampuan berpikir kreatif matematis siswa, karena dapat memaksimalkan kekreatifan siswa sehingga memunculkan ide-ide untuk memunculkan soal dari berbagai kondisi. Pendekatan Problem Posing ini, diharapkan siswa dapat menyusun soal sendiri yang tidak berbeda dengan soal yang diberikan oleh guru sehingga siswa terbiasa dalam menyelesaikan soal termasuk soal cerita dan diharapkan dapat meningkatkan kemampuan berpikir kreatif matematis siswa.

Atas dasar permasalahan dan fakta-fakta yang diungkapkan di atas, maka diadakan suatu penelitian dengan judul "Meningkatkan Kemampuan Berpikir Kreatif Matematis Siswa Kelas XII TKJ SMKN 1 Bireuen dengan Pendekatan Problem Posing".

\section{METODE PENELITIAN Desain Penelitian}

Jenis penelitian ini adalah penelitian eksperimen dengan pendekatan kuantitatif. Menurut Sugiyono dalam (Irawan, 2013) penelitian eksperimen adalah suatu penelitian yang berusaha mencari pengaruh variabel tertentu terhadap variabel lain dalam kondisi yang terkontrol. Pendekatan kuantitatif digunakan karena penelitian ini lebih banyak menggunakan angka-angka dalam pengujian hipotesis. Penelitian ini menggunakan penelitian eksperimen semu (quasi experiment) karena peneliti melakukan pemberian perlakuan kepada subjek penelitian untuk selanjutnya ingin diketahui pengaruh perlakuan tersebut. Perlakuan tersebut adalah pembelajaran dengan pendekatan problem posing tipe presolution posing pada kelas eksprimen dan pembelajaran konvensional pada kelas kontrol.

Desain eksprimen yang digunakan adalah non-equivalen control group design yang digabung dengan desain $2 \times 2$, yaitu dua kelompok pengetahuan awal matematika siswa (tinggi, sedang, rendah), dan dua pendekatan pembelajaran (problem posing, konvensional).
Kelas eksprimen diberi perlakuan pembelajaran problem posing dengan tipe presolution posing $(\mathrm{X})$ dan kelas kontrol menggunakan pembelajaran konvensional tanpa perlakuan khusus. Penelitian ini melibatkan faktor pengetahuan awal matematika (PAM) siswa untuk mengetahui lebih tentang hasil pembelajaran pada kelompok eksprimen, maka dalam

\section{Populasi dan Sampel}

Populasi penelitian ini adalah semua siswa kelas XII SMK Negeri 1 Bireuen tahun pelajaran 2019/2020 yang terdiri dari tujuh belas kelas. Terpilihnya siswa kelas XII berdasarkan pertimbangan bahwa pada tingkatan ini siswa dianggap telah memiliki cukup waktu mengenal lingkungan dan iklim belajar di sekolahnya serta telah memiliki kemampuan dasar matematika yang relatif sama. Dua kelas dari sembilan belas kelas tersebut akan ditetapkan sebagai kelas eksperimen dan kelas kontrol.

Pengambilan data kelas eksperimen dan kelas kontrol dilakukan dengan menggunakan teknik purposive sampling. Teknik purposive sampling digunakan apabila anggota sampel yang digunakan dipilih berdasarkan tujuan penelitian dan pertimbangan tertentu (Arikunto dalam Irawan, 2013). Pertimbangan yang digunakan dalam pengambilan sampel adalah kedua kelas tersebut diajarkan oleh guru yang sama dan mendapatkan perlakuan yang sama. Karena itu, sampel pada penelitian ini adalah kelas XII $\mathrm{TKJ}_{1}$ sebagai kelas eksperimen dan kelas XII TKJ 2 sebagai kelas kontrol.

\section{Variabel Penelitian}

Penelitian ini melibatkan variabel bebas dan variabel terikat. Adapun variabel bebasnya adalah pembelajaran dengan pendekatan problem posing tipe presolution posing dan pembelajaran konvensional. Sedangkan variabel terikatnya adalah kemampuan berpikir kreatif matematis siswa. Selain itu, dalam penelitian ini juga dilibatkan variabel kontrol, yaitu pengetahuan awal matematika (tinggi, sedang, rendah) siswa. 
Kelompok PAM (tinggi, sedang, rendah) siswa ditentukan oleh nilai rapor matematika siswa kelas XII semester ganjil tahun pelajaran 2020/2021. Berdasarkan nilai rapor matematika yang diperoleh maka siswa dikelompokan berdasarkan kriteria dari Somakim (Pamungkas, 2013:47), dilihat dari rerata $(\bar{x})$ dan simpangan baku (sb) sebagai berikut. PAM $\geq \overline{\mathrm{x}}+$ sb siswa kelompok tinggi, $\overline{\mathrm{x}}-\mathrm{sb} \leq \mathrm{PAM}<\overline{\mathrm{x}}+\mathrm{sb}$ siswa kelompok sedang, dan PAM $<\overline{\mathrm{x}}-$ sb siswa kelompok rendah. Hasil perhitungan terhadap data PAM siswa, diperoleh $\overline{\mathrm{x}}=66,64$ dan $\mathrm{sb}=$ 6,05 , sehingga kriteria pengelompokkan siswa adalah PAM $\geq 72,69$ siswa kelompok tinggi, 60,59 $\leq$ PAM < 72,69 siswa kelompok sedang, dan PAM $<60,59$ siswa kelompok rendah

\section{Instrumen Penelitian}

Dalam penelitian ini instrumen yang digunakan adalah tes dan lembar observasi. Instrumen tersebut terdiri dari seperangkat soal tes untuk mengukur kemampuan berpikir kreatif matematis siswa. Hasil pada lembar observasi hanya dijadikan sebagai bahan masukan pagi peneliti dalam melakukan pembahasan secara deskriptif.

Soal tes berbentuk uraian yang disusun berdasarkan indikator kemampuan berpikir kreatif matematis, yaitu kepekaan (sensitivity), kelancaran (fluency), keluwesan (flexibility), keaslian (originality), dan elaborasi (elaboration).

Untuk memperoleh data kemampuan berpikir kreatif matematis, dilakukan penskoran terhadap jawaban siswa untuk tiap butir soal. Kriteria penskoran yang digunakan adalah skor rubrik yang dimodifikasikan dari Bosch (Enden dalam Irawan, 2013).

Rumus korelasi yang digunakan adalah rumus korelasi product moment dari Karl Pearson. Pengujian validitas dilakukan dengan membandingkan thitung dengan tabel. Kriteria yang harus dipenuhi agar koefisien validitas tes termasuk signifikan adalah thitung $>t_{\text {tabel }}$ dengan $\mathrm{t}_{\text {tabel }}=\mathrm{t}_{(1-\mathrm{a})(\mathrm{dk})}$ pada $\mathrm{a}=0,05$ dan $\mathrm{dk}=\mathrm{N}-2$
Berdasarkan pengujian validitas bahwa kedelapan butir soal yang akan digunakan untuk mengukur kemampuan berpikir kreatif matematis adalah valid, sehingga kedelapan soal tersebut dapat digunakan untuk mengukur kemampuan berpikir kreatif matematis dalam penelitian ini.

Untuk menghitung reabilitas perangkat tes dalam penelitian ini digunakan rumus yang sesuai dengan tes uraian, yaitu rumus alphacronbbach (Suherman dalam(Irawan, 2013).

Berdasarkan hasil uji coba dan analisis data menggunakan Microsoft Excel didapat koefisien reabilitas tes sebesar 0,838 yang berarti soal-soal dalam tes yang diujicobakan memiliki reabilitas tinggi.

Untuk hasil perhitungan daya pembeda soal hasil uji coba, disajikan pada tabel berikut ini.

Tabel 2.1 Daya Pembeda Soal Hasil Uji Coba

\begin{tabular}{|c|c|c|c|}
\hline No. & $\begin{array}{c}\text { Nomor } \\
\text { Soal }\end{array}$ & $D_{p}$ & Keterangan \\
\hline 1 & 1 & 0,361 & Cukup \\
\hline 2 & $2 a$ & 0,444 & Baik \\
\hline 3 & $2 b$ & 0,250 & Cukup \\
\hline 4 & 3 & 0,306 & Cukup \\
\hline 5 & 4 & 0,389 & Cukup \\
\hline 6 & 5 & 0,444 & Baik \\
\hline 7 & 6 & 0,250 & Cukup \\
\hline 8 & 7 & 0,389 & Cukup \\
\hline
\end{tabular}

Untuk hasil perhitungan tingkat kesukaran soal hasil uji coba, disajikan pada tabel berikut.

Tabel 2.2 Tingkat Kesukaran Soal Hasil Uji Coba

\begin{tabular}{|c|c|c|c|}
\hline No. & Nomor Soal & $I_{k}$ & Tafsiran \\
\hline 1 & 1 & 0,486 & Sedang \\
\hline 2 & $2 a$ & 0,333 & Sedang \\
\hline 3 & $2 b$ & 0,153 & Sukar \\
\hline 4 & 3 & 0,292 & Sukar \\
\hline 5 & 4 & 0,417 & Sedang \\
\hline 6 & 5 & 0,361 & Sedang \\
\hline 7 & 6 & 0,597 & Sedang \\
\hline 8 & 7 & 0,361 & Sedang \\
\hline \multicolumn{5}{|c|}{ Soal yang digunakan dalam penelitian ini } \\
terdiri dari dua soal yang tingkat kesukarannya
\end{tabular}


sukar dan enam soal yang tingkat kesukarannya sedang. Untuk memperoleh hasil penelitian yang optimal, diadakan kegiatan observasi terhadap pelaksanaan proses pembelajaran terutama pada kelompok eksprimen. Lembar observasi digunakan untuk mengumpulkan data mengenai aktivitas guru dalam menerapkan pendekatan Problem posing pada pembelajaran matematika. Format lembar observasi yang digunakan berupa daftar ceklis hasil pengamatan serta kritik dan saran tentang jalannya pembelajaran yang sedang berlangsung sehingga dapat diketahui aspek-aspek apa yang harus diperbaiki utntuk ditingkatkan. Lembar observasi diisi oleh observer sesuai dengan keadaan pada saat penelitian berlangsung.

Sebelum memulai penelitian, peneliti memberi arahan dan penjelasan kepada observer mengenai yang berkaitan dengan kegiatan observasi. Hasil observasi memberikan gambaran aktivitas guru dan siswa pada setiap kali pertemuan, dan dijadikan bahan refleksi bagi guru untuk memperbaiki proses pembelajaran berikutnya.

Selanjutnya digunakan uji $t$ untuk melihat apakah peningkatan Kemampuan Berpikir Kreatif Matematis (KBKM) siswa kelompok eksperimen lebih baik dibandingkan dengan siswa kelompok kontrol. Dimana hipotesis yang akan diuji adalah:

$\mathrm{H}_{0}: \mu_{1}=\mu_{2}$

(Tidak terdapat perbedaan peningkatan KBKM siswa yang memperoleh pembelajaran problem posing dengan pembelajaran konvensional)

$\mathrm{H}_{\mathrm{a}}: \mu_{1} \neq \mu_{2}$

(Terdapat perbedaan peningkatan KBKM siswa yang memperoleh pembelajaran problem posing dengan pembelajaran konvensional)

Selanjutnya untuk melihat perbedaan peningkatan KBKM siswa yang mendapatkan pembelajaran PP berdasarkan PAM siswa menggunakan Uji ANAVA Satu Jalur dan Uji lanjut dan melihat Interaksi antara PAM siswa dengan pembelajaran terhadap KBKM menggunakan Uji ANAVA Dua Jalur dan Uji lanjut.

\section{HASIL PENELITIAN DAN PEMBAHASAN}

Penelitian dilakukan mulai tanggal 06 Januari sampai dengan 28 Februari 2020. Data diperoleh dari 64 siswa, terdiri dari 32 siswa kelas eksperimen yang memperoleh pembelajaran problem posing dan 32 siswa kelas kontrol yang memperoleh pembelajaran konvensional. Data yang diperoleh kemudian dianalisis yang meliputi pretes, postes, dan gain ternormalisasi dari kemampuan berpikir kreatif matematis siswa kelas eksperimen dan kelas kontrol.

Pretes bertujuan untuk melihat kemampuan awal berpikir kreatif matematis siswa kedua kelas. Postes bertujuan untuk melihat kemampuan berpikir kreatif matematis siswa setelah pembelajaran atau setelah dilakukan penelitian. Data postes penelitian ini digunakan untuk melihat perbedaan kemampuan berpikir kreatif matematis siswa yang memperoleh pembelajaran dengan pendekatan problem posing ditinjau dari faktor PAM siswa (tinggi, sedang, rendah). Data gain ternormalisasi digunakan untuk melihat peningkatan kemampuan berpikir kreatif matematis siswa setelah dilakukan pembelajaran.

Data yang diperoleh dari penelitian ini adalah data kuantitatif dan data kualitatif. Pengolahan data kuantitatif dilakukan dengan menggunakan bantuan software SPSS versi 16.0 for windows. Data kuantitatif diperoleh melalui pretes dan postes kemampuan berpikir kreatif matematis, sedangkan data kualitatif diperoleh dari lembar observasi. Semua hasil penelitian yang dikemukakan pada bagian ini sebagian besar merupakan hasil inferensi dari pengujian statistik.

\section{Deskripsi Pengetahuan Awal Matematika (PAM) Siswa \\ Data PAM siswa merupakan nilai} matematika pada rapor siswa kelas XII semester ganjil tahun pelajaran 2019/2020. Data nilai matematika siswa diperoleh dari guru matematika yang mengajar di kelas $\mathrm{XII} \mathrm{TKJ}_{1}$ dan XII TKJ 2 di SMKN 1 Bireuen. 
Tabel 3.1 Deskripsi PAM Siswa SMKN 1 Bireuen

\begin{tabular}{|c|r|r|r|r|r|}
\hline Kelas & \multicolumn{1}{|c|}{$\mathrm{N}$} & \multicolumn{1}{|c|}{ Minimum } & Maximum & Mean & $\begin{array}{c}\text { Std. } \\
\text { Deviation }\end{array}$ \\
\hline XII TKJ1 & 32 & 60.00 & 80.00 & 66.72 & 6.17 \\
XII TKJ2 & 32 & 60.00 & 80.00 & 66.56 & 6.02 \\
\hline
\end{tabular}

Deskripsi kualitas PAM siswa kelas XII $\mathrm{TKJ}_{1}$ adalah nilai rapor dengan rata-rata 66,72 dengan simpangan baku 6,17 sedangkan kelas $\mathrm{XII} \mathrm{TKJ}_{2}$ memperoleh nilai rapor dengan rata-rata 66,56 dengan simpangan baku 6,02. Dengan demikian, penyebaran data di sekitar rata-rata untuk kelas XII TKJ 2 lebih kecil daripada kelas XII $\mathrm{TKJ}_{1}$. Hal ini menunjukkan bahwa nilai matematika untuk kelas XII TKJ 1 lebih tersebar luas, sedangkan nilai matematika untuk kelas XII $\mathrm{TKJ}_{2}$ lebih terkumpul.

PAM siswa dibagi menjadi tiga kelompok yaitu kelompok siswa dengan PAM tinggi, kelompok siswa PAM sedang, dan kelompok siswa PAM rendah. Pengelompokkan siswa dilakukan sebelum penelitian dimulai yang ditentukan berdasarkan nilai matematika pada rapor semester ganjil tahun pelajaran 2019/2020. Hasil pengelompokkan siswa kedua kelas disajikan pada Tabel di bawah ini.

Tabel 3.2 Pengelompokkan Siswa berdasarkan PAM

\begin{tabular}{|l|c|c|c|c|}
\hline \multirow{2}{*}{ Kelas } & \multicolumn{3}{|c|}{ Kelompok PAM } & \multirow{2}{*}{ Jumlah } \\
\cline { 2 - 5 } & Tinggi & Sedang & Rendah & \\
\hline Eksprimen & 5 & 18 & 9 & 32 \\
\hline Kontrol & 5 & 17 & 10 & 32 \\
\hline Jumlah & 10 & 35 & 19 & 64 \\
\hline
\end{tabular}

\section{Deskripsi Kemampuan Berpikir Kreatif Matematis Siswa}

Data yang dianalisis dalam penelitian ini meliputi skor pretes, postes, dan gain ternormalisasi kemampuan berpikir kreatif matematis siswa kelompok eksperimen dan kelompok kontrol. Setelah dilakukan pengolahan data skor pretes dan postes terhadap kemampuan berpikir kreatif siswa kelas eksperimen dan kelas kontrol diperoleh skor tertinggi, skor terendah, rata-rata skor dan simpangan baku.

Tabel 3.3 Statistik Deskriptif Skor Pretes, Postes, dan Gain Ternormalisasi KBKM siswa

\begin{tabular}{|l|c|r|r|r|r|r|r|}
\hline Kemampuan & \multirow{2}{*}{$\begin{array}{c}\text { Statistik } \\
\text { yang diukur }\end{array}$} & \multicolumn{3}{|c|}{ Kelas Eksperimen } & \multicolumn{3}{|c|}{ Kelas Kontrol } \\
\cline { 3 - 8 } & & Pretes & Postes & \multicolumn{1}{|c|}{ Gl } & Pretes & Postes & \multicolumn{1}{c|}{ Gl } \\
\hline $\begin{array}{l}\text { Berpikir Kreatif } \\
\text { Matematis }\end{array}$ & $\bar{X}$ & 7,59 & 20,28 & 0,40 & 7,66 & 17,28 & 0,52 \\
\cline { 2 - 8 } & $\mathrm{s}$ & 3,03 & 3,80 & 0,14 & 3,52 & 4,26 & 0,15 \\
\cline { 2 - 8 } & min & 2 & 14 & 0,111 & 2 & 11 & 0,150 \\
\cline { 2 - 8 } & mak & 14 & 29 & 0,880 & 15 & 26 & 0,682 \\
\hline
\end{tabular}

Berdasarkan hasil deskriptif skor kemampuan berpikir kreatif diketahui bahwa rerata hasil pretes pada kelas kontrol lebih tinggi daripada kelas eksperimen. Sebelum mendapat perlakuan siswa kelas kontrol rata-rata kemampuan berpikir kreatif siswa lebih tinggi daripada siswa di kelas eksperimen, akan tetapi rerata hasil skor postes kemampuan berpikir kreatif nilai siswa kelas eksperimen lebih tinggi daripada nilai berpikir kreatif siswa kelas kontrol. Setelah mendapat perlakuan siswa di kelas eksperimen memiliki rerata skor kemampuan berpikir kreatif lebih tinggi daripada siswa kelas kontrol. Hal ini dapat ditafsirkan bahwa peningkatan skor kemampuan berpikir kreatif siswa dikelas yang mendapat pembelajaran problem posing lebih baik daripada yang mendapat pembelajaran konvensional.

Terjadi perubahan simpangan baku pada kelas eksperimen yang semula 3,03 meningkat menjadi 4,36 lebih besar daripada kelas kontrol dari 3,52 yang hanya meningkat menjadi 4,09. Nilai simpangan baku kelas eksperimen yang lebih besar ini menunjukkan bahwa variasi sebaran data pada kelas eksperimen beragam. Persentase peningkatan perolehan kemampuan berpikir kreatif matematis dilihat dari skor postes hanya mencapai $63,28 \%$ di kelas eksperimen termasuk kategori sedang dan $53,52 \%$ di kelas kontrol termasuk kategori rendah.

Persentase kemampuan berpikir kreatif matematis siswa berdasarkan tiap indikator menunjukkan adanya peningkatan kemampuan berpikir kreatif matematis siswa baik pada kelas eksperimen maupun kelas kontrol.

Tabel 3.4 KBKM Siswa berdasarkan Tiap Indikator 


\begin{tabular}{|c|c|r|r|r|r|r|}
\hline \multirow{2}{*}{ Kelas } & \multirow{2}{*}{ Kegiatan } & \multicolumn{5}{|c|}{ Indikator } \\
\cline { 3 - 7 } & & $\begin{array}{c}\text { Kelan } \\
\text { caran }\end{array}$ & $\begin{array}{c}\text { Kelu } \\
\text { wesan }\end{array}$ & $\begin{array}{c}\text { Keasli } \\
\text { an }\end{array}$ & $\begin{array}{c}\text { Elabo } \\
\text { rasi }\end{array}$ & $\begin{array}{c}\text { Kepe } \\
\text { kaan }\end{array}$ \\
\hline \multirow{2}{*}{ Eksperimen } & Pretes & 0,92 & 1,41 & 0,44 & 0,88 & 1,22 \\
\cline { 2 - 7 } & Postes & 2,67 & 3,22 & 1,88 & 2,64 & 2,28 \\
\hline \multirow{2}{*}{ Kontrol } & Pretes & 0,83 & 1,34 & 0,44 & 0,88 & 1,23 \\
\cline { 2 - 7 } & Postes & 2,23 & 2,66 & 1,31 & 2,13 & 2,29 \\
\hline
\end{tabular}

Pada kelas eksperimen yang pembelajarannya dengan problem posing, hasil pretes ke lima indikator kemampuan berpikir kreatif matematis, termasuk dalam kategori rendah akan tetapi pada hasil postes menunjukkan adanya peningkatan dua indikator (kelancaran, elaborasi) termasuk pada kategori cukup, dan satu indikator yaitu keluwesan termasuk kategori tinggi. Pada kelas kontrol yang pembelajarannya dengan konvensional, hasil pretes kemampuan berpikir kreatif matematis siswa, ke lima indikator berpikir kreatif matematis termasuk kategori rendah. Hasil postes terdapat satu indikator yaitu keluwesan pada kategori cukup dan empat indikator lainnya termasuk pada kategori rendah.

Dari paparan data itu dapat disimpulkan bahwa pembelajaran problem posing dapat meningkatkan kemampuan berpikir kreatif matematis siswa walaupun hanya satu indikator yaitu keluwesan pada kategori tinggi.

\section{Analisis Postes KBKM berdasarkan Pembelajaran}

Setelah pemberian perlakuan yaitu pembelajaran problem posing pada kelas eksprimen dan pembelajaran konvensional pada kelas kontrol maka kedua kelas tersebut diberikan postes yang sama. Tujuan pemberian postes ini adalah untuk mengukur KBKM siswa setelah dilakukan pembelajaran

Tabel 3.5 Statistik Deskriptif Data Postes

\begin{tabular}{|l|r|r|r|r|r|}
\hline & N & Minimum & Maximum & Mean & $\begin{array}{c}\text { Std. } \\
\text { Deviation }\end{array}$ \\
\hline Kelas Eksperimen & 32 & 14 & 29 & 20,025 & 4,363 \\
Kelas Kontrol & 32 & 11 & 26 & 17,125 & 4,086 \\
\hline
\end{tabular}

Berdasarkan Tabel di atas terlihat bahwa ratarata nilai postes kelas eksperimen dan kelas kontrol adalah 20,025 dan 17,125. Hal ini menunjukkan bahwa nilai rata-rata kelas eksperimen lebih baik daripada kelas kontrol.
Sementara itu, nilai simpangan baku yang diperoleh kelas eksperimen sebesar 4,363 sedangkan nilai simpangan baku pada kelas kontrol sebesar 4,086. Dengan demikian, penyebaran data di sekitar rata-rata untuk kelas eksperimen lebih besar daripada kelas kontrol. Hal ini menunjukkan bahwa data-data untuk kelas eksperimen lebih tersebar luas, sedangkan data-data untuk kelas kontrol lebih terkumpul.

Dikarenakan kedua kelompok data berdistribusi normal dan variansnya homogen, maka untuk mengetahui ada atau tidak adanya perbedaan rata-rata kedua kelompok data berdasarkan kelompok pembelajaran digunakan uji-t. Hipotesis nol yang di uji:

$\mathrm{H}_{0}$ : Tidak terdapat perbedaan postes yang signifikan antara siswa kelas eksperimen dan siswa kelas kontrol

$\mathrm{H}_{\mathrm{a}}$ : Terdapat perbedaan postes yang signifikan antara siswa kelas eksperimen dan siswa kelas kontrol

Kriteria pengujian adalah jika nilai sig. lebih besar 0,05 maka $\mathrm{H}_{0}$ diterima. Hasil uji perbedaan rerata postes KBKM siswa kedua sampel disajikan pada Tabel berikut.

Tabel 3.6 Hasil Uji Perbedaan Rerata Postes KBKM Kedua Kelas Sampel

\begin{tabular}{|c|c|c|r|r|r|}
\hline \multirow{2}{*}{} & \multicolumn{2}{|c|}{$\begin{array}{c}\text { Levene's Test } \\
\text { for Equality of } \\
\text { Variances }\end{array}$} & \multicolumn{3}{|c|}{ t-test for Equality of Means } \\
\cline { 2 - 6 } & $\mathrm{F}$ & \multicolumn{1}{|c|}{ Sig. } & \multicolumn{1}{|c|}{$\mathrm{t}$} & \multicolumn{1}{c|}{ df } & Sig. (2-tailed) \\
\hline Postes Equal variances \\
$\begin{array}{l}\text { assumed } \\
\text { Equal variances not } \\
\text { Assumed }\end{array}$ & .024 & .876 & 2.958 & 62 & .004 \\
\hline
\end{tabular}

Berdasarkan hasil perhitungan di atas, diperoleh nilai sig. $=0,004$ lebih besar 0,05 , sehingga $\mathrm{H}_{0}$ ditolak yang artinya terdapat perbedaan yang signifikansi antara skor postes KBKM siswa yang mendapat pembelajaran problem posing dengan siswa yang mendapatkan pembelajaran konvensional.

Selanjutnya menggunakan Indeks gain untuk mengetahui ada atau tidaknya peningkatan KBKM siswa pada kedua kelas setelah kegiatan pembelajaran dilaksanakan. 
Tabel 3.7 Interpretasi Indeks Gain Kelas Eksperimen dan Kelas Kontrol

\begin{tabular}{|l|c|r|r|}
\hline \multicolumn{1}{|c|}{ Kelas } & $\begin{array}{c}\text { Interpretasi indeks } \\
\text { gain }\end{array}$ & Jumlah & Persentase (\%) \\
\hline \multirow{3}{*}{ Eksperimen } & Tinggi & 5 & 16,63 \\
\cline { 2 - 4 } & Sedang & 26 & 81,25 \\
\cline { 2 - 4 } & Rendah & 1 & 3,13 \\
\hline \multirow{3}{*}{ Kontrol } & Tinggi & 0 & 0 \\
\cline { 2 - 4 } & Sedang & 23 & 71,88 \\
\cline { 2 - 4 } & Rendah & 9 & 28,13 \\
\hline
\end{tabular}

Dari Tabel di atas, nampak bahwa pada kelas eksperimen, hanya ada satu siswa $(3,13 \%)$ yang memiliki indeks gain rendah. Sedangkan pada kelas kontrol, ada 9 siswa $(28,13 \%)$ memperoleh indeks gain rendah.

Deskriptif data indeks gain KBKM siswa kelas eksperimen dan kelas kontrol disajikan dalam Tabel berikut.

Tabel 3.8 Statistik Deskriptif Data Gain

\begin{tabular}{|l|r|r|r|r|r|r|c|}
\hline & $\mathrm{N}$ & Range & $\begin{array}{c}\text { Mini } \\
\text { mum }\end{array}$ & $\begin{array}{c}\text { Maxi } \\
\text { mum }\end{array}$ & Mean & $\begin{array}{c}\text { Std. } \\
\text { Deviation }\end{array}$ & $\begin{array}{c}\text { Varian } \\
\text { ce }\end{array}$ \\
\hline Kelas Eksperimen & 32 & .581 & .261 & .842 & .530 & .145 & .021 \\
Kelas Kontrol & 32 & .532 & .150 & .682 & .394 & .130 & .017 \\
Valid N (listwise) & 32 & & & & & & \\
\hline
\end{tabular}

Data diatas menunjukkan bahwa rata-rata gain ternormalisasi untuk kelas eksperimen dengan pembelajaran problem posing lebih besar daripada rata-rata gain ternormalisasi untuk kelas kontrol dengan pembelajaran konvensional. Gain ternormalisasi (N-gain) pada kelas eksperimen dan kelas kontrol memiliki nilai rata-rata 0,53 dan 0,39 , artinya peningkatan kemampuan berpikir kreatif matematis siswa yang mendapat pembelajaran problem posing dan pembelajaran konvensional berada pada taraf peningkatan sedang

Berdasarkan hasil uji normalitas dan homogenitas, kedua kelas mempunyai data yang berdistribusi normal dan homogen. Selanjutnya digunakan uji $t$ untuk melihat apakah peningkatan KBKM siswa yang ada dikelas eksperimen lebih baik dibandingkan dengan siswa yang ada di kelompok kontrol. Dimana hipotesisnya adalah sebagai berikut:

$\mathrm{H}_{0}$ : Tidak ada perbedaan peningkatan KBKM siswa kelas eksperimen dengan kelas kontrol

$\mathrm{H}_{\mathrm{a}}$ : Peningkatan KBKM siswa kelas eksperimen lebih baik daripada kelas kontrol
Dengan menggunakan taraf signifikansi 0,05, maka kriteria penerimaan hipotesisnya adalah sebagai berikut:

a. Jika $1 / 2$ nilai sig. lebih besar atau sama dengan 0,05 , maka $\mathrm{H}_{0}$ diterima

b. Jika $1 / 2$ nilai sig. lebih kecil dari 0,05 maka $\mathrm{H}_{0}$ ditolak.

Setelah pengujian, diperoleh data seperti Tabel di bawah ini.

Tabel 3.9 Uji Kesamaan Dua Rata-rata Indeks Gain KBKM Siswa Kelas Eksperimen dan Kelas Kontrol

\begin{tabular}{|c|r|r|r|r|r|}
\hline \multirow{2}{*}{} & \multicolumn{2}{|c|}{$\begin{array}{c}\text { Levene's } \\
\text { Test for } \\
\text { Equality of } \\
\text { Variances }\end{array}$} & \multicolumn{3}{|c|}{ t-test for Equality of } \\
Means \\
\cline { 2 - 6 } & F & Sig. & t & df & $\begin{array}{c}\text { Sig. (2- } \\
\text { tailed) }\end{array}$ \\
\hline $\begin{array}{c}\text { Indeks Gain Equal variances } \\
\text { assumed }\end{array}$ & .025 & .876 & 3.960 & 62 & .000 \\
$\begin{array}{c}\text { Equal variances not } \\
\text { assumed }\end{array}$ & & & 3.960 & 61.316 & .000 \\
\hline
\end{tabular}

Dari Tabel diatas terlihat bahwa nilai sig. (2tailed) sebesar 0,000 . Setengah dari nilai sig. ini, $1 / 2(0,000)=0,000$ lebih kecil dari 0,05 . Berdasarkan kriteria pengujian jika nilai $1 / 2$ nilai sig. lebih kecil dari 0,05 maka $\mathrm{H}_{0}$ ditolak. Artinya KBKM siswa yang memperoleh pembelajaran matematika dengan pendekatan problem posing lebih baik peningkatannya daripada siswa yang pembelajaran matematikanya dengan pembelajaran konvensional

\section{Analisis Data Gain Ternormalisasi KBKM berdasarkan PAM Siswa}

Untuk mengetahui peningkatan KBKM berdasarkan PAM siswa, setelah data dikelompokkan menjadi tiga kategori yaitu kelompok tinggi, sedang dan rendah pada siswa yang mengikuti pembelajaran problem posing. Untuk mengetahui perbedaan peningkatan KBKM ketiga kelompok pada kelas eksperimen terlebih dahulu diuji normalitas dan homogenitasnya.

Adapun KBKM siswa berdasarkan kelompok disajikan sebagai berikut.

Tabel 3.10 Deskripsi KBKM berdasarkan PAM Siswa 


\begin{tabular}{|c|c|r|r|r|r|r|r|}
\hline \multirow{2}{*}{$\begin{array}{c}\text { Data } \\
\text { Statistik }\end{array}$} & Kategori & \multicolumn{3}{|c|}{ Kelas Eksperimen } & \multicolumn{3}{|c|}{ Kelas Kontrol } \\
\cline { 3 - 8 } & & Pretes & Postes & N-gain & Pretes & Postes & N-gain \\
\hline \multirow{3}{*}{ Rerata } & Tinggi & 11,60 & 26,80 & 0,75 & 11,80 & 21,00 & 0,46 \\
\cline { 2 - 8 } & Sedang & 7,00 & 20,17 & 0,53 & 7,71 & 17,65 & 0,41 \\
\cline { 2 - 8 } & Rendah & 6,56 & 16,78 & 0,40 & 5,50 & 14,30 & 0,33 \\
\hline \multirow{2}{*}{$\begin{array}{c}\text { Simpangan } \\
\text { baku }\end{array}$} & Tinggi & 1,82 & 1,79 & 0,07 & 2,39 & 3,00 & 0,14 \\
\cline { 2 - 8 } & Sedang & 2,83 & 3,37 & 0,10 & 3,24 & 3,92 & 0,14 \\
\cline { 2 - 8 } & Rendah & 2,19 & 2,77 & 0,09 & 2,59 & 2,91 & 0,09 \\
\hline
\end{tabular}

Dari Tabel tersebut diketahui bahwa nilai gain ternormalisasi KBKM siswa yang pembelajarannya melalui problem posing untuk kelompok tinggi $(0,75)$ termasuk kategori tinggi, sedangkan untuk kelompok sedang $(0,53)$ dan rendah $(0,46)$ termasuk kategori sedang. Sedangkan siswa yang pembelajarannya dengan konvensional, nilai gain ternormalisasi KBKM siswa untuk kelompok tinggi $(0,46)$, sedang $(0,41)$, dan rendah $(0,33)$, termasuk kategori sedang.

Dari data tersebut dapat disimpulkan bahwa kelompok tinggi yang pembelajarannya dengan problem posing termasuk kategori tinggi, sedangkan kelompok sedang dan rendah yang pembelajarannya dengan problem posing termasuk kategori sedang. Kemudian kelompok tinggi, sedang, dan rendah yang pembelajarannya dengan konvensional termasuk pada kategori sedang

Dikarenakan ketiga kelompok data berdistribusi normal dan variansnya homogen, maka untuk perbedaan peningkatan kemampuan berpikir kreatif matematis antara siswa kemampuan tinggi, sedang, dan rendah yang mendapat pembelajaran dengan problem posing diuji dengan uji t. Adapun kriteria pengujian sebagai berikut:

$\mathrm{H}_{0}: \quad \mu_{T}=\mu_{S}=\mu_{R}$

Tidak terdapat perbedaan peningkatan KBKM antara siswa kemampuan tinggi, sedang, dan rendah yang mendapatkan pembelajaran problem posing

$\mathrm{H}_{\mathrm{a}}$ : Paling sedikit satu tanda "=" tidak berlaku Terdapat perbedaan peningkatan KBKM antara siswa kemampuan tinggi, sedang, dan rendah yang mendapatkan pembelajaran problem posing.

Keterangan:

$\mu_{T}=$ rerata skor gain KBKM kategori tinggi
$\mu_{S}=$ rerata skor gain $\mathrm{KBKM}$ kategori sedang

$\mu_{R}=$ rerata skor gain KBKM kategori tinggi

Kriteria pengujian adalah jika nilai sig. lebih besar 0,05 maka $\mathrm{H}_{0}$ diterima. Hasil uji perbedaan peningkatan kemampuan berpikir kreatif antara siswa kemampuan tinggi, sedang, dan rendah kedua sampel disajikan pada Tabel berikut.

Tabel 3.11 Hasil Uji Signifikansi Perbedaan Peningkatan KBKM berdasarkan PAM

\begin{tabular}{|l|r|r|r|r|r|}
\hline & \multicolumn{1}{|c|}{$\begin{array}{c}\text { Sum of } \\
\text { Squares }\end{array}$} & \multicolumn{1}{c|}{ df } & \multicolumn{1}{c|}{$\begin{array}{c}\text { Mean } \\
\text { Squares }\end{array}$} & F & Sig. \\
\hline Between Groups & .384 & 2 & .192 & 20.816 & .000 \\
Within Group & .267 & 29 & .009 & & \\
Total & .651 & 31 & & & \\
\hline
\end{tabular}

Berdasarkan hasil uji ANOVA satu jalur, diperoleh nilai sig. $=0,000$, sehingga $\mathrm{H}_{0}$ ditolak yang artinya terdapat perbedaan peningkatan KBKM siswa antara kelompok tinggi, sedang, dan rendah.

Hal ini berarti KBKM pada kelas eksperimen terdapat minimal dua kelompok kategori (tinggi, sedang, rendah) yang berbeda. Dengan demikian untuk melihat kategori mana saja yang berbeda maka dilakukan uji lanjutan yaitu uji Scheffe.

Tabel 3.12 Uji Scheffe Nilai Rata-rata KBKM Siswa berdasarkan Tingkat PAM

\begin{tabular}{|c|r|r|c|}
\hline Tingkat PAM siswa & $\begin{array}{r}\text { Perbedaan } \\
\text { Rataan }\end{array}$ & \multicolumn{1}{c|}{ Sig. } & Ho \\
\hline Tinggi - sedang & .215 & .001 & Tolak \\
\hline Tinggi - rendah & .345 & .000 & Tolak \\
\hline Sedang - rendah & .129 & .010 & Tolak \\
\hline
\end{tabular}

Pada Tabel diatas terlihat bahwa nilai sig. Untuk pasangan kelompok tinggi dan sedang adalah 0,001 atau kurang dari 0,05 maka hipotesis nol ditolak, sehingga dapat ditarik kesimpulan bahwa KBKM siswa pada kelompok tinggi berbeda secara signifikan dengan siswa pada kelompok sedang.

Demikian pula KBKM siswa pada kelompok tinggi berbeda secara signifikan 
dengan siswa pada kelompok rendah. Hal ini dapat dilihat dari nilai sig. $=0,000$ atau kurang dari 0,05 . Untuk kelompok sedang dan rendah nilai sig. adalah 0,010 atau kurang dari 0,05 maka dapat disimpulkan bahwa terdapat perbedaan signifikan pada KBKM antara siswa pada kelompok sedang dan rendah

\section{Interaksi antara Pembelajaran dan PAM dalam KBKM siswa}

Untuk mengetahui adanya interaksi antara KBKM berdasarkan model pembelajaran dan tingkat PAM. Berdasarkan perhitungan sebelumnya diketahui bahwa KBKM siswa berdasarkan PAM berdistribusi normal, selanjutnya uji homogenitas untuk mengetahui homogenitasnya. KBKM berdasarkan model pembelajaran dan tingkat PAM siswa disajikan sebagai berikut.

Tabel 3.13 KBKM siswa berdasarkan Model Pembelajaran dan Tingkat PAM

\begin{tabular}{|c|c|r|r|}
\hline Data & PAM & Eksperimen & Kontrol \\
\cline { 3 - 4 } Statistik & & Postes & \multicolumn{1}{c|}{ Postes } \\
\hline \multirow{3}{*}{ Rerata } & Tinggi & 26,80 & 21,00 \\
\cline { 2 - 4 } & Sedang & 20,17 & 17,65 \\
\cline { 2 - 4 } & Rendah & 16,78 & 14,30 \\
\hline \multirow{3}{*}{$\begin{array}{c}\text { Simpangan } \\
\text { baku }\end{array}$} & Tinggi & 1,79 & 3,00 \\
\cline { 2 - 4 } & Sedang & 3,37 & 3,92 \\
\cline { 2 - 4 } & Rendah & 2,77 & 2,91 \\
\hline
\end{tabular}

Dari tabel diatas dapat diketahui interaksi antara model pembelajaran dan tingkat PAM siswa dalam menghasilkan KBKM.

Untuk mengetahui apakah varians antar kelompok data sama atau tidak menggunakan Uji Levene.

Tabel 3.14 Uji Homogenitas Pembelajaran dan Tingkat PAM

\begin{tabular}{|r|r|r|r|}
\hline F & df1 & df2 & Sig. \\
\hline 1.230 & 5 & 58 & .307 \\
\hline
\end{tabular}

Berdasarkan data di atas nilai sig. = 0,307 lebih besar 0,05 dapat disimpulkan varians kelompok data adalah sama
Tabel 3.15 Uji Interaksi antara Model Pembelajaran dan Tingkat PAM

\begin{tabular}{|l|r|r|r|r|r|}
\hline Source & $\begin{array}{r}\text { Type III Sum } \\
\text { of Squares }\end{array}$ & df & $\begin{array}{c}\text { Mean } \\
\text { Square }\end{array}$ & \multicolumn{1}{c|}{ F } & Sig. \\
\hline Corrected Model & $.746^{*}$ & 5 & .149 & 11.870 & .000 \\
Intercept & 11.476 & 1 & 11.476 & 912.422 & .000 \\
Pembelajaran & .322 & 1 & .322 & 25.589 & .000 \\
Klp & .374 & 2 & .187 & 14.850 & .000 \\
Pembelajaran * Klp & .080 & 2 & .040 & 3.200 & .048 \\
Error & .729 & 58 & .013 & & \\
Total & 15.124 & 64 & & & \\
Corrected Total & 1.476 & 63 & & & \\
\hline
\end{tabular}

\section{a. Pengujian terhadap Kelompok PAM}

Rumusan hipotesis:

$\mathrm{H}_{0}=$ Tidak ada perbedaan rerata KBKM antara tingkat PAM (tinggi, sedang, rendah)

$\mathrm{H}_{\mathrm{a}}=$ Terdapat perbedaan rerata KBKM antara tingkat PAM (tinggi, sedang, rendah)

Dari Tabel di atas nilai sig. $=0,000<$ 0,05 , kesimpulannya $\mathrm{H}_{0}$ ditolak. Jadi, dapat disimpulkan bahwa terdapat perbedaan peningkatan rerata KBKM antara kelompok PAM (tinggi, sedang, rendah).

\section{b. Pengujian terhadap Pembelajaran}

Rumusan hipotesis:

$\mathrm{H}_{0}=$ Tidak ada perbedaan rerata KBKM antara model pembelajaran problem posing dengan konvensional

$\mathrm{H}_{\mathrm{a}}=$ Terdapat perbedaan rerata KBKM antara model pembelajaran problem posing dengan konvensional

Dari Tabel di atas nilai sig. $=0,000$ lebih kecil 0,05 , kesimpulannya $\mathrm{H}_{0}$ ditolak. Jadi, dapat disimpulkan bahwa terdapat perbedaan rerata KBKM antara model pembelajaran problem posing dengan konvensional.

\section{c. Pengujian terhadap Interaksi Pembelajaran dan Kelompok PAM}

Rumusan hipotesis:

$\mathrm{H}_{0}=$ Tidak terdapat perbedaan rerata KBKM antara pembelajaran problem posing dari 
tingkat PAM dengan pembelajaran konvensional dari kelompok PAM

$\mathrm{H}_{\mathrm{a}}=$ Terdapat perbedaan rerata KBKM antara pembelajaran problem posing dari tingkat PAM dengan pembelajaran problem posing dari kelompok PAM

Kriteria pengujian jika nilai sig $>0,05$ maka terima $\mathrm{H}_{0}$, atau jika nilai sig. $<0,05$, maka tolak $\mathrm{H}_{0}$. Dari Tabel di atas nilai sig. $=0,048$ lebih kecil 0,05, kesimpulannya terdapat perbedaan rerata KBKM antara pembelajaran problem posing dari kelompok PAM dengan pembelajaran problem posing dari kelompok PAM. Jadi terdapat interaksi antara pembelajaran dan kelompok PAM dalam menghasilkan KBKM

Selain penjelasan diatas, salah satu penyebab terjadinya peningkatan kemampuan berpikir kreatif matematis siswa pada pembelajaran dengan pendekatan problem posing adalah adanya kegiatan belajar secara berkelompok untuk menyelesaikan Lembar Kerja Siswa (LKS) yang berisikan situasi-situasi dengan materi yang telah diajarkan di awal pembelajaran. Pengerjaan LKS memberikan kesempatan kepada siswa untuk belajar mandiri. Aktivitas ini dapat membantu meningkatkan ingatan serta pemahaman setelah pembelajaran. Pembelajaran dengan pendekatan problem posing maupun dengan pembelajaran konvensional, siswa telah mengalami proses belajar dimana hasil dari proses belajar ini adalah adanya peningkatan KBKM siswa, walaupun peningkatannya berbeda.

\section{SIMPULAN}

Setelah dilakukan perlakuan berbeda antara dua kelompok sampel yaitu kelas eksperimen yang memperoleh pembelajaran matematika dengan pendekatan problem posing dan kelas kontrol yang memperoleh pembelajaran konvensional maka berdasarkan hasiil analisis data untuk pengujian hipotesisnya, kesimpulan dari temuan yang diperoleh adalah sebagai berikut:
1. Kemampuan berpikir kreatif matematis siswa yang memperoleh pembelajaran problem posing lebih baik daripada siswa yang memperoleh pembelajaran konvensional.

2. Kemampuan berpikir kreatif siswa yang memperoleh pembelajaran problem posing berbeda berdasarkan pengetahuan awal matematika (PAM), yaitu untuk PAM siswa tinggi dengan PAM siswa sedang, PAM siswa tinggi dengan PAM siswa rendah, dan untuk PAM siswa sedang dengan PAM siswa rendah.

3. Terdapat interaksi antara pengetahuan awal matematika siswa dengan pembelajaran yang digunakan terhadap peningkatan kemampuan berpikir kreatif matematis siswa.

\section{DAFTAR PUSTAKA}

Darwanto, D. (2019). Kemampuan Berfikir Kreatif Matematis. Jurnal Eksponen, Volume 9, 20-26.

https://media.neliti.com/media/publications/ 338969-kemampuan-berpikir-kreatifmatematis-pen-7c99dfe1.pdf

Irawan, I. (2013). Pembelajaran Matematika dengan Pendekatan Problem Posing untuk Meningkatkan Kemampuan Berpikir Kreatif Matematis Siswa SMA. Universitas Syiah Kuala.

Nenden, F., \& Isrok'atun, A. N. (2016). Pendekatan Open-Ended untuk Meningkatkan Kemampuan Berpikir Kreatif Matematis dan Kepercayaan Diri Siswa. Jurnal Pena IImiah, 1(1), 1062-1063.

Subhan, A., \& Pamungkas, S. Y. (2017). Peranan Pengetahuan Awal dan Self Esteem Matematis Terhadap Kemampuan Berpikir Logis Mahasiswa. Jurnal Matematika Kreatif - Inovatif. 